ISSN: 2581-8341

Volume 04 Issue 12 December 2021

DOI: 10.47191/ijcsrr/V4-i12-23, Impact Factor: 5.825

\title{
An Exploratory Study to Identify the Factors Affecting the Management of Covid-19 Patients among Nursing Officers at Selected Hospital, Puducherry
}

\author{
Mr. S. Saravanan ${ }^{1}$, Mr. S. Rakesh kumar ${ }^{2}$, Mrs. M. Sasimiltha ${ }^{3}$, Mr. G. Santhosh ${ }^{4}$, Mrs. V. Revathy ${ }^{5}$ (Guide) \\ ${ }^{5}$ Assistant professor in child health nursing Mother Theresa post graduate and research institute of health sciences \\ Puducherry
}

\begin{abstract}
The pandemic outbreak of covid -19 especially caused by the pathogen called corona virus2 (SARS-CoV-2) which causes severe acute respiratory distress syndrome (SARS).This virus especially affects the more elderly individual than youth and more men than women and killed over 80,000 in china. It was established by WHO.
\end{abstract}

KEYWORDS: Nursing Officers, Covid-19, Identify, Management, Factors.

\section{INTRODUCTION}

The newly discovered corona virus (COVID-19) was found in December 2019 which was emerged in city of Wuhan, China and which was affected millions of peoples worldwide and it becomes pandemic disease. COVID_19 has various clinical manifestations ranging from asymptomatic to symptomatic leads to acute respiratory distress syndrome (ARDS) and multiple organ failure, finally death. The World Health Organization (WHO) Infection and Prevention control (IPC) standards suggested that it was pandemic disease so, health facility should offers maximum protection and safety to patients, and health workers. Corona viruses are many crown like spikes on the surface of the virus. It especially spreads by air droplets by when an infected person sings, sneeze, coughs, talk, laugh or breathes nearby another person.

It affected all the age groups with the severe symptomatic and high mortality rate being found among elder peoples and patients with co-morbidities. Many treatment guidelines were provided by WHO for managing the covid-19 patients including tablets, respiratory therapy, ICU treatment, ventilators etc.. Finally it was important to stress that the rated treatment recommendations.

\section{PROBLEM STATEMENT}

An exploratory study to identify the factors affecting the management of covid -19 patients among Nursing officers.

\section{OBJECTIVES}

- To identify the factors affecting the management of covid-19 patients among Nursing officers.

\section{MATERIALS AND METHODS}

\section{Research Approach:}

Research approaches are plans and procedure for research that span the steps from broad assumption to detailed method of data collection, analysis and interpretation. The selection of a research approach is also based on the nature research problem or issue being address the researcher's personal experiences and audience for the study ( John .W. Creswell, 2014)

According to the statement of the problem and to accomplish the study quantitative research approach was adopted.

\section{Research Design}

Research design gives us overall plan for addressing a research question including specification for enhancing the studies integrity. (Polit and Beck 2013).

Non experimental descriptive research design was used to explore the factors affecting the management of covid 19 patients among nursing officers in RGGW \&CH HOSPITAL Puducherry. 


\section{International Journal of Current Science Research and Review}

ISSN: 2581-8341

Volume 04 Issue 12 December 2021

DOI: 10.47191/ijesrr/V4-i12-23, Impact Factor: 5.825

IJCSRR@ 2021

www.ijjesrr.org

\section{Research Variables}

Variables can be defined as any aspect of a theory that can vary or change. In this study the research variable was identifying the factors affecting the management of covid 19 patients.

\section{Research Setting}

Setting is the general location and condition in which data collection takes place for the study (Polit and hungler 2013).The study was conducted at RGGW\& CH HOSPITAL., Puducherry.

\section{Population}

The population refers to a total category of persons or objects that meets out the criteria of study which is set by the Researches. Any set of persons objects or measurement having observable characteristics is common (Polit and Hungler 2013)

In this study, population comprises of all Nursing officers in, Puducherry.

\section{Sample}

A subset of a population comprises of those selected to participate in the study (Polit and Beck (2013)).

The sample for this study were Nursing officers who worked in covid ward during covid-19 pandemics in RGGW\& CH HOSPITAL, puducherry.

\section{Sample Size}

The sample size was 50 Nursing officers working in RGGW\& CH hospital, puducherry.

\section{Sampling Technique}

Purposive sampling technique was used for this study.

\section{SAMPLING CRITERIA}

Inclusion criteria:

* Nursing officers who are willing to participate.

* Nursing officers who are all worked during covid 19 pandemic situation.

* Nursing officers of both male and female

* Nursing officers who are all available at the time of data collection.

\section{Exclusion criteria:}

* Nursing officers who are all not available at the time of data collection.

* Nursing officers who are not willing to participate in data collection.

\section{RESULTS}

\section{SECTION-A}

Table: 4.1 Frequency and percentage distribution of Demographic variables of the Nursing Officers.

\begin{tabular}{|c|c|c|c|c|}
\hline SI.NO & \multicolumn{2}{|c|}{ DEMOGRAPHIC VARIABLES } & FREQUENCY(N) & PERCENTAGE (\%) \\
\hline \multirow[t]{4}{*}{1} & \multirow[t]{4}{*}{ Age } & $20-30$ & 20 & 40 \\
\hline & & $31-40$ & 12 & 24 \\
\hline & & $41-50$ & 13 & 26 \\
\hline & & $51-60$ & 05 & 10 \\
\hline \multirow[t]{2}{*}{2} & \multirow[t]{2}{*}{ Gender } & male & 6 & 12 \\
\hline & & Female & 44 & 88 \\
\hline \multirow[t]{3}{*}{3} & \multirow[t]{3}{*}{ Types of family } & Joint & 13 & 26 \\
\hline & & Nuclear & 37 & 74 \\
\hline & & Extended & 0 & 0 \\
\hline \multirow[t]{2}{*}{4} & \multirow[t]{2}{*}{ Years of experience } & 1 to 5 years & 22 & 44 \\
\hline & & 6 to 10 years & 6 & 12 \\
\hline
\end{tabular}




\section{International Journal of Current Science Research and Review}

ISSN: 2581-8341

Volume 04 Issue 12 December 2021

DOI: 10.47191/ijesrr/V4-i12-23, Impact Factor: 5.825

IJCSRR@ 2021

www.ijcsrr.org

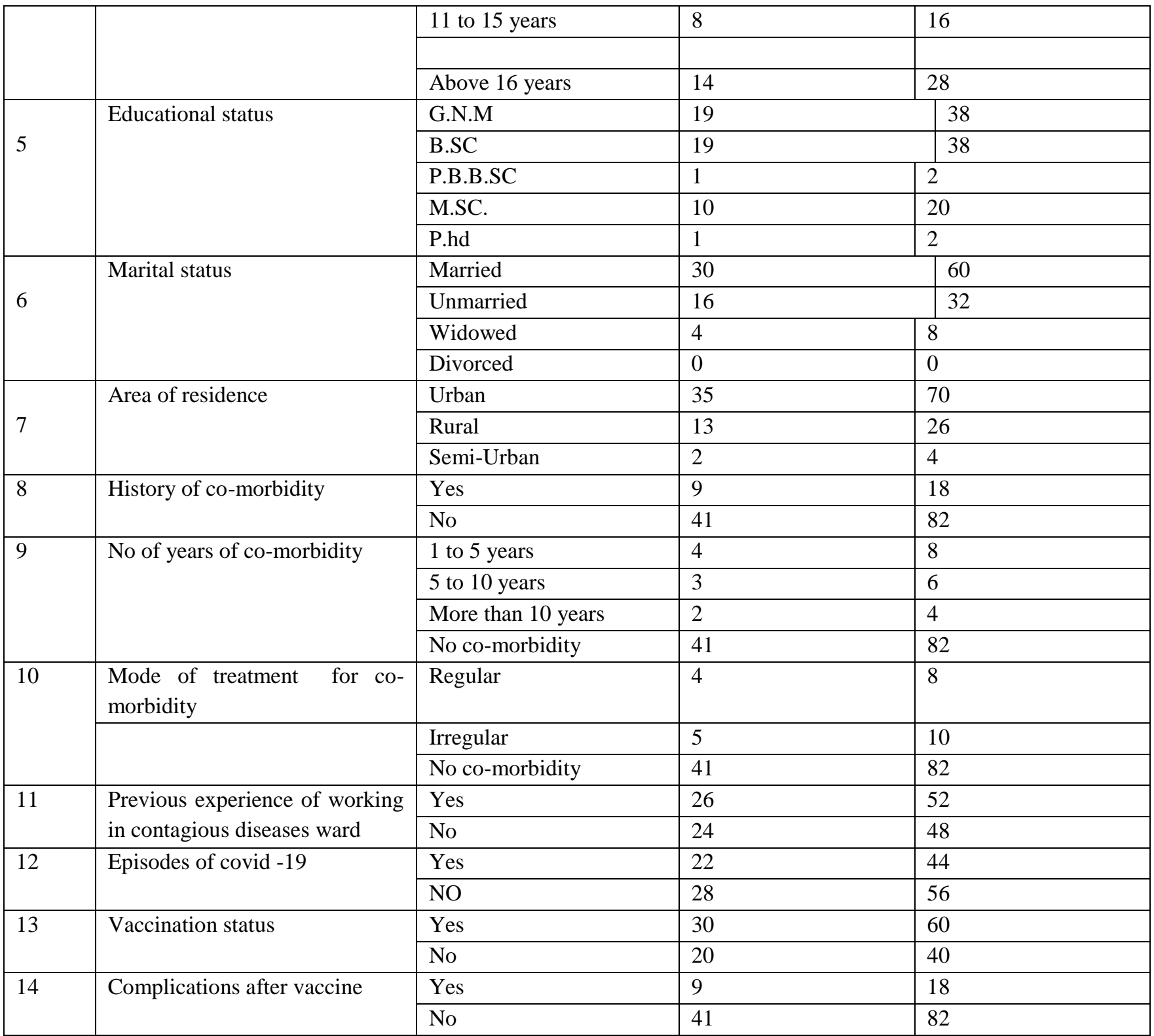

\section{SECTION -B}

Table-4.2 Frequency and percentage distribution of the factors affecting the management of covid-19 patients.

\begin{tabular}{|l|l|l|}
\hline FACTORS & RESPONSES & PERCENTAGE \% \\
\hline physical & 232 & $31.4 \%$ \\
\hline psychological & 269 & $36.4 \%$ \\
\hline social & 237 & $32.1 \%$ \\
\hline
\end{tabular}

From the above table, it was evident that majority of the factors affecting the management of covid-19 patients were the psychological factors $(36.4 \%)$

The checklist was analyzed using descriptive statistics (frequency, percentage distribution was used to analyze the data). The data was analyzed and discussed on the objectives of the study. 


\section{International Journal of Current Science Research and Review}

ISSN: 2581-8341

Volume 04 Issue 12 December 2021

DOI: 10.47191/ijcsrr/V4-i12-23, Impact Factor: 5.825

IJCSRR@ 2021

\section{DISCUSSION}

Around 50 Nursing Officers in RGGW\&CH, Puducherry, were selected for this study. From the above table 4.1, findings were discussed below,

\section{Major Findings of the Study are Discussed as Follow:}

* Majority of the Nursing Officers belong to the age group of $20-30$ years (40\%)

* Majority of the Nursing Officers were females (88\%)

* Most of the Nursing Officers belong to nuclear family (74\%).

* Majority of the nursing officers have 1 - 5 years of experience (44\%)

* Most of the nursing officers have studied the course B.Sc and GNM (38\%)

* Majority of the nursing officers are married (60\%)

* Most of the nursing officers residing in urban area (70\%)

* Majority of the nursing officers do not have co-morbid illnesses (82\%)

* Most of the nursing officers had previous experience of working in contagious disease wards (52\%)

* Majority of the nursing officers have been vaccinated with COVID 19 Vaccine (60\%)

* Majority of the factors affecting the management of COVID patients among the nursing officers were the psychological factors. $(36.4 \%)$

The objective of the study was to identify the factors affecting the management of COVID patients among Nurses.

Results highlights that among 50 samples, physical factors (31.4\%), psychological factors (36.4\%) and social factors (32.1\%) affects the management of COVID 19 patients among Nursing Officers

\section{Significant Findings of the Study}

- 20 (40\%) Nursing Officers belong to 20-30 years of age, 12 (24\%) belongs to 31-40 years of age, 13 (26\%) belongs to 41 50 years of age, $5(10 \%)$ belongs to 51-60 years of age

- $44(88 \%)$ of Nursing officers were females and $6(12 \%)$ were male.

- $37(72 \%)$ of Nursing officers belongs to nuclear family, 13(26\%) belongs to joint family and none of the Nursing officers belongs to extended family

- $\quad 22(44 \%)$ Nursing officers had 1-5 years of experience ,6 (12\%) had 6- 10 years of experience,8 (16\%) had 11-15 years of experience , 14(28\%) had above16 years of experience.

- $19(38 \%)$ Nursing Officers have completed GNM, 19(38\%) BSc, 1(2\%) PBBSC, 10(20\%) MSc and 1(2\%) Doctorate.

- $30(60 \%)$ of Nursing Officers are married, 16(32\%) unmarried, widowed 4(8\%) and no one have divorced.

- $13(26 \%)$ of Nursing officers are from rural area, 35(70\%) from urban area and 2(4\%) from semi urban area.

- $\quad 41(82 \%)$ of nursing officers has no co-morbid illness, $9(18 \%)$ have co-morbid illness.

- $4(8 \%)$ Nursing officers has 1 to 5 years of co-morbid illness, $3(6 \%)$ has 5 to 10 years of co morbid illness and 2 (4\%)has 10 to 15 years

- 4 nursing officers are on regular treatment and 5 are on irregular treatment out of 9 members with co-morbid illness.

- $26(52 \%)$ nursing officers had experience of worked in contagious disease wards, 24(48\%) had no experience..

- $28(56 \%)$ nursing officers did not had an episode of Covid 19, 22(44\%) had an episode.

- $30(60 \%)$ nursing officers got vaccinated for covid and $20(40 \%)$ had not vaccinated

- $9(18 \%)$ Nursing officers had complications after COVID vaccine, $41(82 \%)$ didn't have any complications.

Results highlights that among 50 samples, physical factors (31.4\%), psychological factors (36.4\%) and social factors (32.1\%) affect the management of COVID 19 patients among Nursing Officers.

\section{CONCLUSION}

Recent newspaper reports show that COVID-19 patients increasingly mistrust institutionalized health care due to the lack of reliability of the treatment at public and private hospitals caused by testing scandals and a preference for home-based treatment. The stakeholders should take appropriate measures so that patient confidence in the health-care system can be restored. The study 


\section{International Journal of Current Science Research and Review}

ISSN: 2581-8341

Volume 04 Issue 12 December 2021

DOI: 10.47191/ijcsrr/V4-i12-23, Impact Factor: 5.825

IJCSRR@ 2021

WWW.ijesrrorg

concluded that the factors affecting the management of COVID-19 patients among Nursing Officers in RGGW\&CH, Kathirgamam, Puducherry, were physical factors $(31.4 \%)$, psychological factors $(36.4 \%)$ and social factors $(32.1 \%)$.

\section{RECOMMENDATIONS}

- A similar study can be conducted for identifying the factors affecting the management of COVID 19 patients among other health care workers.

- A similar study should be conducted among the COVID 19 patients about the care provided.

- A survey to identify the health care workers at greater risk of acquiring COVID 19 infection

- An experimental study can be conducted to find out the effectiveness of disseminating information regarding the factors affecting management of COVID patients

- This study can be replicated on a larger sample for generalizing the findings.

\section{BIBLIOGRAPHY}

Book Reference

1. Coronavirus Disease 2019 (COVID-19). (2020). In S. K. Saxena (Ed.), Medical Virology: From Pathogenesis to Disease Control. Springer Singapore. https://doi.org/10.1007/978-981-15-4814-

2. Tlili, A., Amelina, N., Burgos, D., Othman, A., Huang, R., Jemni, M., Lazor, M., Zhang, X., \& Chang, T.-W. (2020). Remote Special Education During Crisis: COVID-19 as a Case Study. In Lecture Notes in Educational Technology (pp. 69-83). Springer Singapore. https://doi.org/10.1007/978-981-15-7869-4_5

3. Polit Denise F and Beranadetle P Hungler(1991) "Text book of Nursing research" 4th

4. Edition, phila Delphia Lippincott Williams Wilkins, Page No:86-90.

5. BBT Basvanthappa (2005) "Text book of Nursing Research" 2nd edition, New Delhi Jaypee publisher (n) ltd, page No:470-484.

6. Kothan (1996) "Text Book of Nursing Research"7th edition, Lippincott William publishers New Delhi, Page No:45-54.

7. Suresh K Sharma „Nursing research and statistic" Second edition Elsevier publication india pg no:321-340

\section{Journals Reference}

1. Mersha, A., Shibiru, S., Girma, M. et al. Perceived barriers to the practice of preventive measures for COVID-19 pandemic among health professionals in public health facilities of the Gamo zone, southern Ethiopia: a phenomenological study. BMC Public Health 21, 199 (2021).

2. Tirupakuzhi Vijayaraghavan, B. K., Nainan Myatra, S., Mathew, M., Lodh, N., Vasishtha Divatia, J., Hammond, N., Jha, V., \& Venkatesh, B. (2020). Challenges in the delivery of critical care in India during the COVID-19 pandemic. Journal of the Intensive Care Society, 175114372095259. https://doi.org/10.1177/1751143720952590

3. Salas, J. B., Palacios, J., Dintrans, P. V., Madero-Cabib, I., Quilodran, R., Ceriani, A., \& Meza, D. (2020). Enablers and Barriers to Implement COVID-19 Measures in Long-term Care Facilities: A Mixed Methods Implementation Science Assessment in Chile. Research Square. https://doi.org/10.21203/rs.3.rs-125014/v1

4. Lotfi, M., Hamblin, M. R., \& Rezaei, N. (2020). COVID-19: Transmission, prevention, and potential therapeutic opportunities. Clinica Chimica Acta, 508, 254-266. https://doi.org/10.1016/j.cca.2020.05.044

5. 5. Lakshmi Priyadarsini, S., \& Suresh, M. (2020). Factors influencing the epidemiological characteristics of pandemic COVID 19: A TISM approach. International Journal of Healthcare Management, 13(2), 89-98. https://doi.org/10.1080/20479700.2020.1755804

6. Aristovnik, A., Keržič, D., Ravšelj, D., Tomaževič, N., \& Umek, L. (2020). Impacts of the COVID-19 Pandemic on Life of Higher Education Students: A Global Perspective. Sustainability, 12(20), 8438. https://doi.org/10.3390/su12208438

7. Algunmeeyn, A., El-Dahiyat, F., Altakhineh, M. M., Azab, M., \& Babar, Z.-U.-D. (2020). Understanding the factors influencing healthcare providers' burnout during the outbreak of COVID-19 in Jordanian hospitals. Journal of Pharmaceutical Policy and Practice, 13(1). https://doi.org/10.1186/s40545-020-00262-y 


\section{International Journal of Current Science Research and Review}

ISSN: 2581-8341

Volume 04 Issue 12 December 2021

DOI: 10.47191/ijesrr/V4-i12-23, Impact Factor: 5.825

IJCSRR@ 2021

www.ijcsrr.org

8. Mattila, E., Peltokoski, J., Neva, M. H., Kaunonen, M., Helminen, M., \& Parkkila, A.-K. (2020). COVID-19: anxiety among hospital staff and associated factors. Annals of Medicine, 53(1), 237-246.

Net Reference

1. https://doi.org/10.1080/07853890.2020.18629tp://dx.doi.org/

2. www.e.2016.v12n1p46

3. www.gooogle.com

4. St. www.yahoo.com

5. www.medline.com

6. www.pubmed.com

7. www.mediineplus.com

8. www.onlinejournal.

Cite this Article: Mr. S. Saravanan, Mr. S. Rakesh kumar, Mrs. M. Sasimiltha, Mr. G. Santhosh, Mrs. V. Revathy(2021). An Exploratory Study to Identify the Factors Affecting the Management of Covid-19 Patients among Nursing Officers at Selected Hospital, Puducherry. International Journal of Current Science Research and Review, 4(12), 1782-1787 